Indonesian Journal of EFL and Linguistics

Vol. 5 No. 1,2020

eISSN: 2503-4197, pISSN: 2527-5070

www. indonesian-efl-journal.org

\title{
The Dimension of Discourse in English Class of Higher Education
}

\author{
Soraya \\ STBA LIA Jakarta, Indonesia \\ e-mail: soraya@stbalia.ac.id
}

\begin{abstract}
:
The research aims to describe the dimension of discourse and identity of English lecturers. This research is conducted with a qualitative approach and content analysis method. The data source is recordings of classroom interaction of English lecturers. The data are analyzed using the classroom discourse framework of Betsy Rhymes which focuses on dimensions, namely social context, interactional context, and individual agency. These dimensions are analyzed through the source of turn takings, contextualization clues, narration, and framing. The result shows that in social context, the lecturers negotiate the interaction by giving more turns to the students, applying all the contextualization clues to accompany the utterance and supporting the interaction with narration and frame all to support students' contribution. In interactional context, the lecturers include the experience of the students in all sources and use vernacular language. In individual agency, the lecturers include all students in a challenging and inclusive activity. The conclusion of the research is that the interaction in the classroom discourse dimension is influenced by the standard of education and the condition of students who lack confidence to speak English as the social context which influences the use of language in the class. However, the personal control of the lecturers to achieve the standard of education makes him/her manage the language use to provide context of interaction in order to make the students contribute to the interaction.
\end{abstract}

Keywords: Classroom Discourse Analysis, Classroom Interaction, Dimensions of Discourse

Indonesian Journal of EFL and Linguistics, 5(1), 2020 


\section{Soraya}

\section{INTRODUCTION}

In higher education level, generally, a lecturer expects critical thinking from the students. According to Badan Standar Nasional Pendidikan (BSNP, 2010), learning should be cultivated in a democratic atmosphere so that the learners are courageous to deliver ideas. Whitehead (in Ramsden, 2003 p.7) stated that "the often articulated aim is that university students should develop the ability to think critically." Thus, it takes lots of practice to generate critical thinking. The lecturer should have the ability to make the students get engaged so that they can have "broad mindedness, imagination, creativity and critical thinking skills as well as values such as tolerance towards other cultures, mutual respect of differences and hard-work"(Lazrak \& Yechouti, 2017 p. 87).

Generating critical thinking means that the learning process should enable the students to actively speak the mind. The students should have the qualities beyond the cognitive skills. They must have the academic, personal, and social quality in order to reach the expectation of a higher education student. According to Sahinkarakas, Inozu, \& Yumru, (2010, p. 4183), "classroom experiences and curriculum are not the only influences on college outcomes. Thus, identifying potential linkages between various types of experiences, both formal and non-formal, and different dimensions of student growth is crucial in enhancing our understanding of the diverse factors that play critical role in learning and personal development (of higher education students)"

However, one of the challenges faced by universities and other institutions of higher education in the $21 \mathrm{st}$ century is that teaching and learning must be more active, connected to real life, and designed with students and their unique qualities in mind (Granados, 2010; Lazrak \& Yechouti, 2017). Teaching in higher education takes more than just the ability to carry out routine activities of teaching and learning. Thus, higher education will benefit if those who teach inquire into the effects of their activities on their students' learning because through the discussion in the class, the lecturers and the students are exchanging ideas and experience.

Furthermore, such implementation is one of the obstacles in a foreign language class (Walsh, 2006). In an English as a foreign language class (EFL), mostly, the lecturers arrange the learning activity and control almost all of the conversation. In such conditions, the lecturers dominate the classroom talk. The situation creates imbalance in the classroom interaction. Ellis as quoted from Rani, Arifin, and Martutik (2004) stated that teacher decide who can talk, start and close the talk, decide the length of the talk. It makes "the roles of the participants (teacher and learners) are not equal. They are asymmetrical” (Walsh, 2011, p. 4). A study by Rashidi \& Rafieerad (2010) revealed that the teacher dominated the talk in the EFL classroom. In such situation, there is a gap between students' expected ability, which is ability to generate critical thinking, and the realization in the learning process.

Many lecturers, then, focus on finding teaching methods to improve students' ability in English. Nevertheless, the quality of learning achievement is not solely determined by 
the methods. Interaction process actually shapes the learning achievement because 'learning and teaching are constantly interchanging activities.... Interaction in the class influences the educational environment in which they learn profoundly affects students' thoughts and actions" (Ramsden, 2003, p. 8). The effect of interaction will determine the ability of students to generate critical thinking. Thus, the qualities needed in order to be an outstanding lecturer are the qualities such as informative, interesting and engaging so that students can follow the information, logic, and ideas (Morton, 2009). Moreover, a lecturer should be able to make students leave the class knowing that "they have learned something(s), and are often inspired to go off and find out more" (Morton, 2009 p. 59).

In order to create learning atmosphere which involves critical thinking and creativity, a lecturer needs to have mastery in communicating the learning material, either spoken and written, verbally and non-verbally. Students learning experience in the class is closely related to language since all information and activities are transferred by using language. The language used by the lecturers when delivering the learning material (medium of instruction) determines the interaction in the learning process. In fact, classroom interaction between the lecturers and the students is the most important access to the language learned (Hyland, 2009). Learning process in the class is also influenced by the application of prosodic features, vocabulary, and grammar. Language realization in the class combined with the material and learning strategy creates classroom context. Thus, lecturers who know about language use in the class will create better learning (Edwards \& Westgate, 2005). "Language, in relationship to the social construction of life in classrooms, refers to the oral and written discourse norms, expectations, and strategies that members establish through their daily interactions. In short, the language-of- the-classroom is a group of constructed phenomena, a negotiated system of meaning, and a set of conventions for interacting, participating and communicating information and knowledge within a particular classroom (Behnam \& Pouriran, 2009, p.118)

In complex interaction situations, lecturers and students are key elements because the lecturer processes the various components of the interaction and presents it to students. Without an appropriate response from students, interaction will be difficult to take place. Interaction is the key to teaching English because students will improve their language skills when they listen and use their English skills. An English lecturer must have English competence which fulfills the standard, either for specific goals (formal or informal communication) or for educational goals (Mayuni, 2007). Thus, language competence of lecturers is not at cognitive level anymore but at real communication level. If teachers want to be effective to promote the learning, they need not only to understand communication but also to improve it (Walsh, 2011). They should be more like facilitators, trainers, and companions in the learning process as Ramsden (2003) stated that teaching needs the ability to speak and listen equally. In that case, Johnson (quoted in Walsh, 2006) stated that the understanding classroom discourse dynamics is important to maintain communication practice for the lecturers. The research of 
Mustapha (2010) pinpoints that in the class, role of the lecturers to prompt the students to participate in the conversation is crucial because the lecturers' interpersonal styles play a central role in classroom interaction.

To get a complete picture of the lecturers create interaction in higher education English class, this research aims to investigate (1) the social context of English class at STBA LIA, (2) the interactional context of English class at STBA LIA, and (3) the individual agency of English class at STBA LIA.

\section{LITERATURE REVIEW}

\subsection{Classroom Interaction}

Classroom interaction is the most important element in the EFL teaching. Classroom interaction is a pedagogical activity (Walsh, 2011) because all learning activities, ranging from elicitation, discussion of material, to evaluation in class are done through interaction. Without good interaction, pedagogical goals will be difficult to achieve. Moreover, communication in the classroom is "the central to teaching" (Walsh, 2011) as teacher use the language to manage the people, to organize the activity, to deliver the lesson, etc. (Walsh, 2011; Prasetyo, R. Iguh; Mulyani, 2018). In short, classroom interaction is the center of the learning process and the most important element in curriculum because learning does not happen through the interaction but in the interaction process (Walsh, 2006). For students in EFL class, interaction centered on communicative competence and the language was obtained when they are actively involved interacting to communicate with the target language (Kalantari, 2009). Students' engagement on the interaction will benefit socially and academically. Ellis, as quoted by (Wasi'ah, 2016), stated that interaction occur not only in social interaction but also inside the mind when constructing a comprehension or a situation. Thus, classroom interaction plays important role in succeeding language learning process because everything that happens in the classroom happens through a process of live person-to-person interaction.

However, maintaining students' contribution in the classroom interaction is not easy. There is a tendency that students remain passive unless the lecturer ask them to speak. In higher education, this situation will hinder the generating of critical thinking. The research from $\mathrm{Yu}$, (2010) shows that students will talk only when they are given chances because they are afraid of making mistakes. In such situation, the lecturer needs to modify the interaction and raise the need for students to express themselves. The research of Rashidi \& Rafieerad (2010) shows that to avoid a teacher-dominated classroom, teachers should reorganize the activities which can foster more interaction in the classrooms that students will be motivated to learn, and possess positive attitude towards language learning since they resemble real life events. In some situation, a lecturer needs to modify a situation so that students actively involved in the interaction. Mustapha, (2010) stated that "When class participation is a part of evaluation that determines the overall grade for the course, students are more likely to be motivated to participate and engage in their own learning" (p. 92). 


\subsection{Classroom Discourse}

Classroom discourse is different from discourse in any other institution. In the class, domination of teacher talk is considered natural. Ellis as quoted from Rani, Arifin, and Martutik (2004) stated that teacher decide who can talk, start and close the talk, decide the length of the talk. It makes "the roles of the participants (teacher and learners) are not equal. They are asymmetrical" (Walsh, 2011, p. 4). A study by Rashidi \& Rafieerad (2010) revealed that the teacher dominated the talk in the EFL classroom. However, this kind of interaction is the feature of classroom discourse. Classroom discourse analysis is an approach that is considered capable enough to unravel the problem of language use in teaching and learning interactions (Prasetyo, R. Iguh; Mulyani, 2018). It also provides a method to learn how to communicate various languages of teacher and students (Rymes, 2016)

The study on classroom discourse structure firstly introduced by Sinclair and Couthard (1975) in his work Introduction to Discourse Analysis. They introduced the model of discourse involving five level in hierarchical order - from the lowest to the highest are act, move, exchange, transaction and interaction unit where the higher unit contains the lower ones. They also found that exchange units called initiation-response and Follow up (IRF). The IRF structure is the traditional exchange happens in the classroom. It was proven by $\mathrm{Yu}$ (2009) who studied the classroom discourse of English for nonEnglish major at university level. He found out that IRF dominated the exchange. The application of IRF is related to the experience. With more teaching experience, a lecturer can modify the exchange in the classroom so that there can be variety of interaction exchange from lecturer and students. Hamzah, (2019 p.276) stated that the "experience of English teachers contribute the ability in modifying internal structure of exchange.

Most of discourse analysis is concerned with speaking because the talk in the classroom between teacher and students is one of the most important ways that learners can gain access to the language they are trying to learn (McCarty\& Walsh, 2003). This is reflected in the interaction continuum in learning in the English class (Hall, 2011).

\begin{tabular}{|c|c|c|c|}
\hline & $\begin{array}{l}\text { Instructional } \\
\text { discourse }\end{array}$ & 'Convivial discourse' & Natural discourse \\
\hline Roles & Fixed statuses & & Negotiated roles \\
\hline Tasks & Teacher-oriented & & Group-oriented \\
\hline $\begin{array}{l}\text { Types of } \\
\text { knowledge }\end{array}$ & Focus on accuracy & & $\begin{array}{l}\text { Focus on meaning } \\
\text { and fluency of } \\
\text { interaction }\end{array}$ \\
\hline
\end{tabular}

Figure 1. Interaction continuum

When teaching, the lecturers can manage interactions on the interaction lines according to the type of knowledge expected. Lecturers can direct interactions with students to focus on accuracy or fluency according to the learning needs and language abilities of 
students. When focusing on meaning and fluency, teacher can modify the roles or the structure of exchanges. The focus of learning can be adjusted to the learning objectives and the ability of participants (students) to use the language in the classroom.

Generally, discourse is defined as language in use (Rymes, 2008). Words, sentence, or grammatical form are chosen by an interlocutor and uttered by paying attention to the context of language use. In classroom discourse, the class is the main context. An analysis of a classroom will generate a language use description which is natural and specific based on the context of classroom setting. The research of Bukhari \& Xiaoyang (2013) stated that that CDA is useful to investigate the relationship between teaching, learning, and curriculum, and school and community as well as ideologies and power and their impacts on the classroom process and teaching-learning activity.

Classroom context in critical classroom analysis is more than the classroom itself. It covers the context which affects what is being interpreted in the class. Whatever is said in the class is influenced by the context outside the classroom because the lecturer and the students have experiences which influence the discourse in the class. The beliefs and expectations of parents, institution managers, and government outside the classroom and the relationship between teachers and students in the classroom affect the practice of learning in the classroom (Hall, 2011).

\subsection{Critical Classroom Discourse}

An analysis of classroom discourse becomes critical classroom discourse when the variable of social context outside the classroom is considered in the analysis. Studies in the field of English language teaching are now starting to pay attention to the sociocultural context, institutional (educational) discourse, teacher and student interactions, and so on because classroom is a social environment and language learning is an activity based on social relations and social interaction. Critical Classroom Discourse Analysis (CCDA) assumes that classroom reality is socially constructed, politically motivated, and historically determined (Sadeghi, Ketabi, Tavakoli, \& Sadeghi, 2012).

Thus, to investigate a classroom discourse, there are three dimensions to be analyzed: social context, interactional context, and individual agency (Rymes, 2008b). Social context is the factors outside the class which influenced what can be said or done in the classroom. Interactional context is the order/pattern of the conversation in the interaction which influences what is said and how other interlocutors interpret it in the discourse. Individual agency is the influence or personal control of how words are being used and interpreted in the interaction. The relationship of the three can be seen in figure 2. 


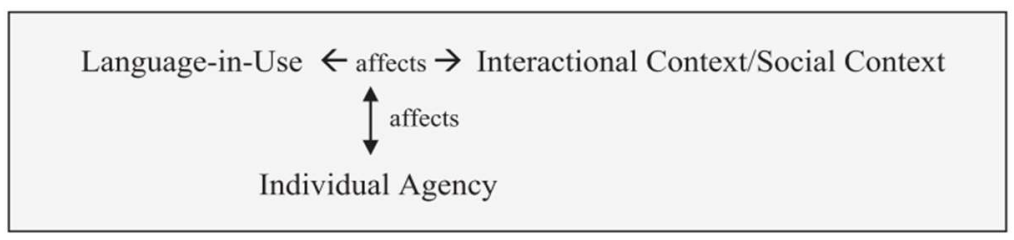

Figure. 2. Relationship of dimensions and identity (Rymes, 2008)

Social context dimension will be investigated based on the language use. Interactional dimension will focus on the interaction between the lecturers and the students in the class. Language use and interaction will influence one's individual agency. In the class, it is related to the powerfulness or personal control of lecturers on the lesson planning, material delivery, or assessing the comprehension to realize the lesson objective. The three dimensions will be analyzed through the turn taking, contextual resources, narration, and framing source.

a. A classroom's intellectual life can be built by taking turns, asking and answering questions, providing feedback and encouraging more thinking (Rymes, 2008). turn taking is concerned with pedagogical content knowledge as it encompasses four interrelated components, namely 'knowledge of students, knowledge of environmental contexts, knowledge of pedagogy and knowledge of subject matter' (Nomlomo, 2011). The turn taking in the class will create patterns, whether it is traditional, initiation-response- feedback or initiation-response-evaluation (IRF/IRE), or non-traditional. The IRF exchange is associated with power relations and control (Nomlomo, 2011) and it often restricts the learners from expressing their views and understanding of subject content, especially in classrooms where the learners are taught in an additional language. The initiations mostly start with questions, whether it is closed ended (procedural) or open-ended questions. The last one is usually lead to discussion in the class because it is substantive. According to Rymes (2008), turn taking is controlled by both interactional context of the classroom, and the different patterns of interaction students bring to the classroom from home and community contexts.

The research of Nomlomo, (2011) found that turn-taking approaches can be associated with power relations and certain socio-cultural factors in a number of ways because teacher starts the turn taking, select the next speaker. The power distance between teachers and learners may lead to fears and anxiety, which may have negative effects on learner participation during the teachinglearning process. Also, teachers' previous experiences and beliefs influence their classroom practices and interaction. Teachers who experienced active involvement in their learning are have tendency to facilitate active learning in their teaching. In classroom interaction, turn-taking is usually initiated by the 
teacher through asking questions or giving instructions, while learners acquire or receive turns by responding to the teachers' questions or instructions. The ability of lecturer to create question when initiating the turn taking will improve students' critical thinking skills because high-level questioning stimulates students' active participation and facilitates learning. Also when asking question, a lecturer actually triggers and interrelates students ${ }^{\text {ee }}$ prior knowledge with new information and assists them in reconstructing knowledge (Bulent et al., 2016).

b. Contextual resources can be in form of prosodic/paralinguistic and nonverbal expressions which belong to either the lecturer or students. The most nonverbal cues in class, body language can send messages about attitude, emotional state, and desire to control our environment (Di, 2014). Nonverbal cues are also powerful to enhance classroom teaching (Muchemwa, 2013; Di, 2014). Variations of contextualization cues is also related to the register and the types of questions. Registers are ways of speaking that vary according to activity. It can be casual or formal. In any classroom, discourse analysis can reveal that varying registers will produce different effects.

c. In the class, students and the lecturer share narration. Narration in the class is instigated by questions. The narratives can be shared, either directly through their statements, or indirectly through teaching aids such as pictures, video, and other teaching materials to infuse the life's experiences with meaning and relevance. Even though, the teaching instructors has full power to determine the narration stated in the class, they should use narratives to help students able to apply the lesson to their personal lives. When students can recognize the relevant information in the narrative, they are taking the critical first step toward higher levels of cognitive processes and meaningful learning (Kromka \& Goodboy, 2019) because teachers "must be able to hear all our students' stories - not just those select few that correspond to our expectations" (Rymes, 2008, p.258). In certain situation, the teaching instructor can help students to narrate (co-author) their stories experience, ideas, or thoughts).

d. In the classrooms, each person comes to class with the thought, habits, and relationships that frame the classroom talk (Rymes, 2008). The contextual frame that is brought to the class constructs the language used. In other words, discourse and its frame are in a dialectical relationship. The frame brought to the class is known as the voice. The teacher's voice plays the key role in the teaching-learning process (Rodrigues, Medeiros, \& Teixeira, 2016; (Rennie Center for Education Research \& Policy, 2019). A lecturer becomes a facilitator in the teaching-learning dynamic through the use of the voice. On the other hand, student voice refers to the student participation and decision making in the structures and practices that shape their educational experiences. Student voice can also be the result of learning experiences that help build students' sense of efficacy and elevate their opinions (Rennie Center for 
Education Research \& Policy, 2019). Receiving the message in the class, students interpret the content in order to get engaged in the learning

\section{RESEARCH METHODOLOGY}

The approach of the research is qualitative. This research can be categorized in sociolinguistics because the characteristics of the problem is related to phenomena of social aspects in language. The subjects of the research are 10 English lecturers of STBA LIA with 3-30 years teaching experience with expertise in teaching English.

The data collection is done by recording the classroom interaction, individual interview, and focus group discussion (FGD) of the English lecturers. The interactions are recorded in English skills and English content subjects. The individual interview and the FGD are conducted to obtain information/data which can't be obtained through the recording.

The research design applied is content analysis using critical classroom discourse of Rymes (2008) to see the social context, interactional context, and personal control which influence the interaction in the classroom.

\section{FINDINGS}

All the interaction of 10 English lecturers in the class analyzed by critical classroom discourse framework by Betsy Rymes. There are 434 data found in classroom interaction which are analyzed in the dimension of social context, interactional context, and personal agency,

\subsection{Social context of English Class}

Based on the turn taking, mostly, the lecturers focus on including the students experience. From 434 data, the lecturers only include their own experience in 40 data. It shows how lecturers maximize the chance for the students to relate the discussion in the class with the life of the students so that it will be easier for them to follow. Only two data show that students can't follow the discussion. It is also supported by the form of turn taking which are mostly substantive. It means that the interaction involving meaningful interaction. It is meaningful because in elicitation, explaining concept, or evaluating student's comprehension, the lecturers ask or give examples using the students experience so that the response from the students are genuine. The procedural turn taking is limited only for checking the students exercise.

The analysis of contextualization in the interactional context shows that there are variations of register. The lecturers use formal and formal colloquial. The lecturers rarely use non-verbal clues. However, to maximize the interaction and to make the students get the idea of what is being discussed, the lecturers use various expressions necessary. The expression helps the students to get the meaning so that there won't be be misunderstanding.

From the analysis of narration, mostly the lecturers state their statement/story indirectly by using video in form of personal experience. Usually the lecturers provide 
narration to elicit the students' schemata, to explain and illustrate a concept, and to trigger discussion. Mosty, narration is provided in eliciting schemata and discussion. The narration is built by using positive words. The narration often builds together with the students so that it is not seen as the idea deliver solely by the lecturers. The involvement of other students as co-author makes the concept easier to comprehend by the students and make the students think that they can get involve in the class discussion. It also lessens the domination of the lecturers in the class.

In the analysis of framing, it shows that the voice from outside the class is delivered directly with participation structure from the lecturers to the whole class. The voice framed is delivered individually when certain students need to be encouraged. Thus, the number is not significant. although the voice framed is the voice outside the classroom, the decision maker in the delivery is the lecturers. The voice is delivered to all students. The sentences formed to deliver the voice is mostly simple sentence in imperative form. The simple sentence used because the idea in the sentence is single so that it won't lead to misunderstanding for the students. The words mostly are verbs and adjectives which shows what to do and how to see the situations. Therefore, the ideas framed can be grasped by the students.

\subsection{Interactional context of English Class at STBA LIA}

Based on the data, it was found that in Interactional context, the lecturers are more active to initiate the interaction. From 434 data found, only six data of interaction started by the students. The students lack of confidence to speak English. This situation makes the lecturers need to mantain the students' contribution.

However, the lecturers manage most of the turn taking by using non-traditional structure. Non-traditional turn taking means that the lecturers do not use the InitiationResponse-Feedback (IRF) pattern. The non-IRF pattren enable the lecturers to give opportunity for the student's answer, elaborate, and relate the material with their personal life. After the students give the response, the lecturers prolong the conversation by asking more questions, asking other students to give comments, or checking the student's comprehension by relating the response with materials. The non-traditional pattern functions well to make the students to talk.

To maintain the students' participation, the lecturers also modify the questions. Mostly, the lecturers raise open-ended questions. They pose more open questions to enable students to think and speak English better than using the questions from the textbook or general questions. The non-traditional patterns are applied with contextualization cues such as intonation, volume, and waiting time. The lecturers also use teaching aids, for instance video, to stimulate the students participation.

The lecturers also deliver new information in narration which are inserted in elicitation, concept explanation, and after discussion. The narration delivered mostly indicates bigger concept so that it can be related to the experience of the students, the 
explanation, and suggestion from the lecturers. Despite the focus of interaction given to the students, the one determine the correct answer mostly is the lecturers.

From the framing source, the voice from outside the class is delivered by the lecturers. The lecturers mention what is expected from the students through the narration, the excerpt in the material, and explanation about the quality good students expected by the school, parents, curriculum, etc.

\subsection{Individual Agency of English Class at STBA LIA}

Based on the analysis of individual agency from the turn taking data, most of the data individual agency inform that the turn taking patterns create challenging and inclusive data. It happens because the lecturers always elaborate students' experience and checking students' understanding in the interaction.

Based on the analysis of contextualization, the one which has the voice in the class is the lecturers because they control the voice in the class with general contextualization cues, whether it's verbal or prosodic. Also, the lecturers provide sistemic cues in form of language variation and language switching to make the concept, example, and material explained clear.

In general, narrations in the individual agency are trigerred through discussion, video showing, or providing illustration. Thus, the narrations can be either from the lecturers or from the students. For example, when the lecturers ask the students to give example, illustration, or opinion. At other situation, the lecturers can show videos to give stories or provide illustration to help the students' comprehension. In that way, as the narrator in the class, the lecturers still frame and control the narrations in the class.

However, the data also show that the lecturers often involve other students in narration as co-authors. It is done because the lecturers realize that involving other students when delivering narration will give chances for the students to contribute in the interaction. Thus, the lecturers will not be the sole source of information in the class. The effect of involving students as co-author makes the students realize that they can contribute to the class interaction.

Based on analysis of framing, the lecturers have created new way to bring the voice from outside the class. The voice can be narrated by the students by asking them to share experience or to ask them playing if situation. The voice which gives advice is given through sharing experience, so that the students do not realize that the lecturers are educating them for the better personal quality.

\section{DISCUSSION}

Analysis of three dimensions (social context, interactional context, and individual agency) confirms that situation in ELT classroom is dominated by the teachers or the lecturers who control almost all the conversation as stated by Walsh, (2006), Rymes, (2008), Rashidi \& Rafieerad, (2010), and Domalewska, (2015). This asymmetrical contribution creates gap in the interaction. The same situation is also found in the 
research of Behnam \& Pouriran, (2009). Furthermore, it confirms the research of Yu (2010) in which most students hesitate to start the interaction because they are afraid of making mistakes and that students will talk only when they are given chances.

However, different from the research of $\mathrm{Yu}$ (2010), who found that most of the interaction pattern in ELT class is IRF, the present study shows that the dominant pattern in interactional context is non-IRF. Somehow, this turn taking creates larger contribution in students' participation. Nomlomo (2011) stated that IRF pattern shows power relation and control. This study shows that non-IRF pattern can also show power and control in individual agency. When the lecturers are able to identify the relation of experience, inside and outside the classroom (Sahinkarakas et al., 2010), they are able to create active and connected-to-real-life learning (Granados, 2010). The lecturers realize that the interaction affect the thoughts and action, as stated by (Ramsden, 2003). Therefore, they create most interaction with non-IRF pattern in substantive and inclusive way. It makes the students relate the questions with their experience and thoughts so that the response is genuine. Such situation shows teacher ability to speak and listen equally (Ramsden, 2003). The lecturers limit the procedural activity only for checking students' response in the exercises. Posing substantive questions have prompted students to respond more (Mustapha, 2010; Bulent et al., 2016; Rymes, 2008).It makes the learning meaningful in interactional and social dimension. The findings also show the importance of turn taking and questioning.

Moreover, in order to make the interaction meaningful, the lecturers modify the language by using formal and colloquial language combined with various expressions. The analysis of contextualization cues shows that through such contextual cues, the students to get the meaning so that there won't be misunderstanding. The application of the language makes students understand the content of the interaction. As the responses, they contribute more in the interaction and language use. Thus, the application of the proper contextualization cues provides access to the classroom interaction as the key to learn the language (Hyland, 2009). The findings confirm what is stated by Edwards \& Westgate (2005) and Behnam \& Pouriran (2009). This situation shows that the lecturers form the learning context and interaction with various contextualization cues, from managing the intonation, giving waiting time, etc. so that the classroom discourse is formed. The discourse also forms the learning interactional context (Johnstone, 2008).

Analysis of narration in all dimensions shows that the lecturers mostly stated their voice. In some situations, the lecturers also state their voice indirectly through videos or personal stories. Such narration is easier for the students to follow. By doing this, the lecturers focus the learning to the students' thought and experience as the immediate learning context. The immediacy is also supported by formal colloquial form of language in situations provided by the video showing. Thus, the students feel that they are talking about something that they know. It increases their involvement in the interaction. The lecturers make an effort to create flexible interaction to generate students to talk. In other words, the narrations are used not only as learning material 
but also as helping contexts to illustrate the background of the material, to trigger the students' contribution, and to deliver message/voices from outside the class so that students can increase the personal quality. The contribution in of students show the communicative competence and they learn the language as they involve in interaction (Kalantari, 2009).

Analysis of framing shows that the teacher applying their voice with some strategies. Prolonging the interaction to include students' thoughts and ideas in non-IRF turn taking has increased the number of students' voice. When students need encouragement to be better in learning, the lecturer can voice their thoughts. They also bring the voice from outside the class for more support. However, when students voice their thoughts, the lecturer provide chance and support by coauthoring so that the students can talk better. This study confirms that students voice can be the result of learning experience (Rennie Center for Education Research \& Policy, 2019).

Analysis of dimensions of social context and interactional context indicate that the lecturer did not apply of the power by dominating the interaction. Instead, they create interaction which reduce the domination though less turn taking, applying non-IRF, using colloquial registers, indirect narration, and coauthoring students voice. However, it shows that it is part of the strategy in order to get more contribution from the students. As stated by Behnam \& Pouriran (2009), interaction needs expectation and strategies. It is also confirmed by the research of (Shamsipour \& Allami, 2012) that in order to have a better second language classroom, teachers should be aware of all the interactional features which lead to the improvement of second language classroom or in another word a second language teacher should become the researcher of his own practice. The use of turn taking, contextualization cues, narration, and framing in contextualization cues in general create response of preferred interaction. The data analysis shows that social context and interactional context influence each other to create individual agency of the lecturers. The individual agency to create better interaction in the class and to achieve the learning objective, the lecturers plan and manage the interaction. Because of that, their experience and opinion is always extracted as part of interaction. The lecturers are no longer the sole infomediary in the class because they can use the knowledge and experience of the students as the learning source.

The lecturers' awareness that the social context in form of the expected goal influence the the lecturers personal control to manage the turn taking, contextualization cues, narration and the way to frame the voice from outside the class in increate the students' interaction. On the other hand, the personal control also increase the awareness of the lecturers about the social context, that there is a gap between students' present quality and the expected goal which need to bridge. The lecturers realize that the learning objective of English students: the ability of doing critical thingking and the language competence should be achieved. Thus, the lecturers modify the interaction in order to achieve the expected goal. 


\section{CONCLUSION}

In conclusion, creating interactive classrooms shows the power of the lecturer to apply the strategy by modifying the turn taking, contextual cues, narration, and framing sources. Thus, the interaction in the classroom discourse dimension at STBA LIA is influenced by the standard of education and the condition of students who are lack of confidence to speak English as the social context which influence the use of language in the class. However, the personal control of the lecturers to achieve the standard makes them manage the language use to provide context of interaction in order to make the students contribute in the interaction well.

\section{REFERENCES}

Behnam, B., \& Pouriran, Y. (2009). Classroom discourse : analyzing teacher / learner interactions in iranian efl task- based classrooms. Porta Linguarum, 12(junio), $117-132$.

BSNP. (2010). Paradigma Pendidikan Nasional Abad XXI. 1-59.

Bukhari, N. H. S., \& Xiaoyang, W. (2013). Critical discourse analysis and educational research. IOSR Journal of Research \& Method in Education (IOSRJRME), 3(1), 09-17. https://doi.org/10.9790/7388-0310917

Bulent, D., Erdal, B., Ceyda, A., Betul, T., Nurgul, C., \& Cevahir, D. (2016). An analysis of teachers questioning strategies. Educational Research and Reviews, 11(22), 2065-2078. https://doi.org/10.5897/err2016.3014

David, N. (Ed.). (2003). Practical English language teaching. Singapore: McGrawHill Companies.

Di, Z. (2014). The non-verbal communication in english classroom teaching. (January 2014). https://doi.org/10.2991/iemb-14.2014.123

Domalewska, D. (2015). Classroom discourse analysis in EFL elementary lessons. International Journal of Languages, Literature and Linguistics, 1, No.1(March), 6-9. https://doi.org/10.7763/IJLLL.2015.V1.2

Edwards, A. D., \& Westgate, D. P. G. (2005). Investigating classroom talk (Second). London: Taylor \& Francis e-library.

Gee, J. P. (2005). An introduction to discourse analysis (Second). London: Routledge.

Granados, J. (2010). The challenges of higher education in the 21 st century - Global University Network for Innovation. (April 2011). Retrieved from www.guninetwork.org/resources/he-articles/the-challenges-of-higher-educationin-the-21st-century

Hall, G. (2011). Exploring English language teaching: Language in action. London: Routledge

Hamzah, H. (2019). Structure of Classroom Discourse Produced by English Teachers of Different Experience to Different Level of Proficiency Group. 276(Icoelt 
2018), 33-39. https://doi.org/10.2991/icoelt-18.2019.5

Hyland, K. (2009). Academic discourse: English in a global context. London: Continuum

Johnstone, B. (2008). Discourse analysis (Second). Malden: Blackwell Publishing Ltd.

Kalantari, R. (2009). Techniques for classroom interaction. International Journal of Language Studies, 3(4), 425-434.

Kromka, S. M., \& Goodboy, A. K. (2019). Classroom storytelling: using instructor narratives to increase student recall, affect, and attention. Communication Education, 68(1), 20-43. https://doi.org/10.1080/03634523.2018.1529330

Lazrak, M., \& Yechouti, Y. (2017). Issues in Moroccan Higher Education. International Journal of English \& Translation Studies, 5(2), 86-93.

Muchemwa, S. (2013). Use of Nonverbal Communication in the Classroom as a Way of Enhancing Classroom Teaching: A Case Study of Solusi High School, Zimbabwe. Procedia - Social and Behavioral Sciences, 103(November 2013), 1279-1287. https://doi.org/10.1016/j.sbspro.2013.10.457

Mustapha, S. M. (2010). Understanding Classroom Interaction: A Case Study of International Students 'Classroom Participation at one of the colleges in Malaysia. International Journal for the Advancement of Sceince and Arts, 1(2), 91-99.

Nomlomo, V. (2011). Classroom interaction: Turn-taking as a pedagogical strategy. Per Linguam, 26(2). https://doi.org/10.5785/26-2-21

Prasetyo, R. Iguh; Mulyani, M. (2018). Teacher's directives speech actsin teachinglearning interactions:classroom discourse analysis. Seloka, 7(3), 213--221. https://doi.org/https://doi.org/10.15294 /seloka.v7i3.26607

Ramsden, P. (2003). Learning to teach in higher education (second). New York: RoutledgeFarmer https://doi.org/10.1080/03075079312331382498

Rashidi, N., \& Rafieerad, M. (2010). Analyzing patterns of classroom interaction in EFL classrooms in Iran. Journal of Asia TEFL, 7(3), 93-120.

Rennie Center for Education Research \& Policy. (2019). Student Voice: How Young People Can Shape the Future of Education.

Rodrigues, A. L. V., Medeiros, A. M. de, \& Teixeira, L. C. (2016). Impact of the teacher's voice in the classroom: a literature review. Distúrb Comun, 29(1), 2-9. https://doi.org/10.23925/2176-2724.2017v29i1p2-9

Rymes, B. (2008). Classroom discourse analysis: A tool for critical reflection. New Jersey: Hampton Press

Sadeghi, S., Ketabi, S., Tavakoli, M., \& Sadeghi, M. (2012). Application of critical classroom discourse analysis (CCDA) in analyzing classroom interaction. English Language Teaching, 5(1), 166-173. https://doi.org/10.5539/elt.v5n1p166

Sahinkarakas, S., Inozu, J., \& Yumru, H. (2010). The influence of higher education experiences on ELT students' learning outcomes. Procedia - Social and Behavioral Sciences, 2(2), 4183-4188. https://doi.org/10.1016/j.sbspro.2010.03.661

Shamsipour, A., \& Allami, H. (2012). Teacher Talk and Learner Involvement in EFL 
Soraya

Classroom: The Case of Iranian Setting. Theory and Practice in Language Studies, 2(11), 2262-2268. https://doi.org/10.4304/tpls.2.11.2262-2268

Walsh, S. (2006). Investigating classroom discourse. London: Routledge

Walsh, S. (2011). Exploring classroom discourse. London: Routledge.

Wasi'ah, N. (2016). a Study of Teacher Talk in Classroom Interaction At an Islamic Senior High School. OKARA: Jurnal Bahasa Dan Sastra, 10(1), 29. https://doi.org/10.19105/ojbs.v10i1.809

$\mathrm{Yu}$, W. (2010). An Analysis of College English Classroom Questioning. Journal of Language Teaching and Research, 1(2), 152-159. https://doi.org/10.4304/jltr.1.2.136-144 